\title{
Francis Crick
}

\section{Hunter of Life's Secrets}

\begin{abstract}
Thoru Pederson
Program in Cell and Developmental Dynamics; Department of Biochemistry and Molecular Pharmacology; University of Massachusetts Medical School;

Worcester, MA USA
\end{abstract}

Review of: Olby, Robert C. Francis Crick: Hunter of Life's Secrets. Cold Spring Harbor Laboratory Press, Cold Spring Harbor, NY: 2009.

Key words: x-ray diffraction, DNA, triplet code, central dogma

Submitted: 01/06/10

Accepted: 01/06/10

Previously published online: www.landesbioscience.com/journals/ nucleus/article/11174
Beyond archival details of birthplace, family and education, biographers face a formidable challenge to record someone who, in the subject's brashness, might have seemed to have left in his tracks nothing unsaid about himself or in accounts by others who found themselves in his amazing company. In his autobiography Francis Crick came across as an eloquent and basically decent man (as I knew him to be). ${ }^{1}$ On the history of science front, his two great discoveries (the double helix and the triplet code) have been treated in considerable epistemological depth. ${ }^{2-6}$ And in addition to his autobiography, Crick was recently portrayed in a succinct but vibrant biography.?

Robert Olby came to his subject with the soundest of credentials, having written The Path to the Double Helix, sui generis. ${ }^{2}$ Moreover, he knew Crick quite well and had the supportive collaboration of contemporaries, family members andthe biographer's fortunate muse: a long serving secretary of the subject who kept detailed notes.

Crick's childhood and early career are developed meticulously, conveying a penetrating picture of the key influences that buffeted this odd but apparently brilliant young man. Crick was not a top exam grade student yet everyone was in awe of him early on. As to overall style, the author's attention to non-scientific detail is remarkable. For example, in reading about the "Green Door", a tiny apartment in Cambridge the Cricks rented in his "pre-idol" era, the reader can almost divine the kitchen's sink-to-refrigerator distance (nearly short enough to warrant using Angströms as the measure).
On the DNA work, Olby describes the sequence of both theoretical and empirical events in handsome detail (the former under-developed in some accounts), illuminating how brilliantly and consistently Crick was at the fore. The tensions with Maurice Wilkins and Rosalind Franklin are developed in depth, including how Crick tried to help Franklin by sharing his mathematics for solving diffraction patterns generated from a helix, part of his Ph.D. work on horse hemoglobin. Olby brings forth all the complex circumstances in an unbiased manner, including Wilkins' declination to be a co-author on the Watson and Crick Nature paper, the authors' non-acknowledgement of Franklin's work and their enduring concerns during the following months that the structure might well be wrong.

In contrast to the DNA story, how Crick and Brenner got the triplet code is less well known to many outside molecular biology. This was a much greater intellectual accomplishment than the double helix because there was no antecedent empirical foundation to be read or borrowed. Olby describes this last stage of Crick's bench work in great depth and his account leaves the reader breathless for what Crick and Brenner were able to figure out from these phage experiments. The Meselson-Stahl experiment may have been the "most beautiful", as the late Frederic Lawrence Holmes labeled it, ${ }^{8}$ but Olby's riveting description of the triplet code work reminds us of the possibility that the discovery of the triplet code was on the same high ground of experimental ingenuity. 
Once Crick had solved DNA and the code he tackled two new problems. One was biological pattern formation, specifically the case of insect epidermis. For a time, Crick's ideas in this classical corner of developmental biology attracted some attention but in the long term came to naught. Then he got keen about chromosome structure and what the histone proteins do. Crick messed around (literally) in this for a couple of years. It is often assumed that Crick helped Roger Kornberg in the latter's discovery of the nucleosomal structure of chromatin, but Olby correctly conveys a different slant, namely that Crick was no "kind mentor" to Kornberg but was in fact something of a competitor. Indeed, a proposed (and ultimately erroneous) chromatin structure Crick had published earlier became a source of severe disappointment to him and possibly even mild depression - a mood to which Crick succumbed more than once over his career when an idea fell short.

Crick's later career in neuroscience, in which he tackled consciousness, was a tougher road for Olby, as it would be for any biographer. Consciousness is not, at least as it first presents itself, a problem of biological structure where Crick's training and accomplishments had been, but rather is an emergent property of nothing less than the human brain. Legions of neuroscientists had pondered the problem, but perhaps none the likes of Crick. Yet, in two decades of sustained effort he felt that he had failed. Anyone wishing to know how Crick's own mind worked will find it all laid out in a remarkable book he wrote when deep into this project. ${ }^{9}$ Crick thought that even something like consciousness, which he later reduced to the hopefully more tractable problem of visual processing, could be approached and perhaps even solved, by sheer intellectual penetration. It was not to be. In remembering this great man one might stop and consider the fact that he even tried. Olby covers this era of Crick's career, at the Salk Institute, in empathic depth and also describes his final illness with both intimacy and sensitivity. Throughout the book Olby does true justice to Francis' creative, fun-loving, artistic and devoted colleague, Odile Crick, standing with him all the years but never more gratefully by Francis than in those happy and then closing La Jolla years.

All throughout, Olby intersperses detailed accounts of the science with Crick's persona. Neither perspective is at the expense of the other and together they enable and elevate the book, the two wound together in the mutual relationship of a helix. The personal details are as interesting as the science and, if anyone was wondering-yes, a genius like Crick was not uncomplicated. His exploits beyond the lab are all there and he was indeed adventuresome. One time when we were dining Francis turned to my wife and asked "Do you go to nudist colonies?" She replied: "I prefer nudity at home." This produced one of his characteristic outbursts of high-pitched laughter whose frequency and wattage could come close to piercing an eardrum.

I suppose reviews of a biography could be divided into ones by those who knew the subject versus those who did not. I knew Francis Crick quite well and think Olby has gotten him right on all scores. Crick was guarded on first encounter but once he thought a person was "OK" he let all loose. He knew and trusted Robert Olby and the result has given us something truly memorable.

In the opening line of his book, (at first infamous, now justly famous), Jim Watson said he had never seen Crick in a modest mood. I would say that I never saw him in less than a keenly observant mood, wanting to go over data and think about what it meant. Yes, he didn't suffer fools gladly and yes, it is true that he erupted more than once at a meeting when an ill-fated speaker hadn't thought deeply enough about the data. But I knew him as a very kind man, yet a ferocious genius, usually unable to stop himself as the neurons fired down onto his tongue. There has never been anyone like Francis Crick in the modern era of biology, and Robert Olby has revealed this truth with profound insight.

\section{References}

1. Crick F. What Mad Pursuit. A Personal View of Scientific Discovery. Basic Books, New York 1988.

2. Olby R. The Path to the Double Helix. University of Washington Press, Seattle 1974.

3. Portugal FH, Cohen JS. A Century of DNA. MIT Press, Cambridge MA 1977.

4. Judson HF. The Eight Day of Creation. Simon and Schuster, New York, London 1979.

5. Judson HF. Reflections on the histiography of molecular biology. Minerva 1980; 18:369-421.

6. Kay LE. Who Wrote the Book of Life? A History of the Genetic Code. Stanford University Press 2000

7. Ridley M. Francis Crick. Discoverer of the Genetic Code. Harper Collins, New York 2006.

8. Holmes FL. Meselson, Stahl and the Replication of DNA. A History of "The Most Beautiful Experiment in Biology". Yale University Press, New Haven, London 2001.

9. Crick F. The Astonishing Hypothesis. Simon and Schuster, New York, London 1994 